UDC 339.9:331.5:004.5

DOI: https://doi.org/10.32782/2520-2200/2019-3-5

Tul Svitlana

Higher Educational Establishment of Ukoopspilka "Poltava University of Economics and Trade"

Туль C.I. старший викладач кафедри міжнародної економіки Вищого навчального закладу Укоопспілки «Полтавський університет економіки і торгівлі»

\title{
SYSTEMIC TRANSFORMATION OF BUSINESS AND LABOR MARKET IN THE CONDITIONS OF DIGITALIZATION
}

\section{СИСТЕМНА ТРАНСФОРМАЦІЯ БІЗНЕСУ ТА РИНКУ ПРАЦІ В УМОВАХ ДІДЖИТАЛІЗАЦІІ}

The article determined that the high penetration of the Internet and information and communication technologies all over the world creates opportunities for the digital economy development. At the same time, it was noted that the process of digitalization of the economy in different countries is unequal. It was proved that in case of digital economy formation digitalization of business became the main condition for its effective functioning. It was justified that the digitalization of business should be considered as the source of deep systemic transformations in the economy and involves the usage of digital technologies at the business level to optimize business processes, increase company productivity and improve interaction with customers. In the digital economy, the digitalization of labor market is of particular importance. It was proved that the transformation of labor market implies the exponential increase in the number of electronic labor exchanges and online labor platforms that form a single global labor market.

Key words: digital business, digital economy, digital enterprise, digital technologies, digital transformation, digitalized labor market, electronic labor exchanges, online labor platforms.

В статье было определено, что быстрые темпы распространения Интернета и информационно-коммуникационных технологий создают возможности для развития цифровой экономики. В то же время было отмечено, что процесс диджитализации экономики в разных странах мира является неравномерным. Было доказано, что в условиях формирования цифровой экономики диджитализация бизнеса стала основным условием для его эффективного функционирования. Было обосновано, что диджитализация бизнеса должна рассматриваться как источник глубоких системных трансформаций в экономике и предполагает на уровне бизнеса использования цифрровых технологий для оптимизации хозяйственных операций, повышения производительности компании и улучшения взаимодействий с клиентами. Особое значение в цифровой экономике приобретает новое явление - диджитализация рынка труда. Было доказано, что трансформация рынка труда предполагает экспоненциальное увеличение количества электронных бирж труда и платформ онлайн-занятости, формирующих единый глобальный рынок труда.

Ключевые слова: цифровой бизнес, цифровая экономика, цифрровое предприятие, цифровые технологии, цифровая трансформация, диджитализированный рынок труда, электронные биржи труда, платформы онлайн-занятости.

У статті було визначено, що швидкі темпи поширення Інтернету та інформаційно-комунікаційних технологій створюють можливості для розбудови цифрової економіки. Водночас було відзначено, що процес діджиталізації економіки у різних країнах світу є нерівномірним. Було доведено, що в умовах формування цифрової економіки діджиталізація бізнесу стала основною умовою для його ефективного функціонування. Було обґрунтовано, що діджиталізація бізнесу повинна розглядатися як джерело глибоких системних трансформацій в економіці і передбачає на рівні бізнесу використання цифрових технологій для оптимізації господарських операцій, підвищення продуктивності компанії та поліпшення взаємодії з клієнтами. Для сучасних компаній питання діджиталізації стосується не лише технологічної модернізації, а також повної зміни бізнес-процесів: обслуговування клієнтів, системи створення доданої вартості продукції та/або послуг, процесів обробки даних, системи впровадження інновацій, управління людськими ресурсами. Осо- 
бливого значення у цифровій економіці набуває нове явище - діджиталізація ринку праці. Було доведено, що трансформація ринку праці передбачає експоненційне зростання кількості електронних бірж праці та платформ онлайн-зайнятості, які фрормують єдиний глобальний ринок праці. У цифровій економіці спостерігається істотне збільшення кількості незалежних самозайнятих професіоналів, які виконують різні види робіт дистанційно від місця розташування роботодавця на основі використання цифрових технологій через електронні біржі праці. Сформований єдиний діджиталізований ринок праці створює не лише позитивний економічний ефект, оскільки сприяє зменшенню витрат часу та фрінансових ресурсів бізнесу на пошук висококваліфікованих кадрів унікальної спеціалізації), а також соціально-демографічний, надаючи можливості для реалізації потенціалу знань, навичок та вмінь незалежними самозайнятими професіоналами у галузях, в яких вони є компетентними.

Ключові слова: цифровий бізнес, цифрова економіка, цифрове підприємство, цифррові технології, цифрова трансформація, діджиталізований ринок праці, електронні біржі праці, платформи онлайн-зайнятості.

Formulation of the problem. The large-scale penetration of modern information technologies leads to the business sector's transformation, manifested in the transition from traditional entrepreneurship to high-tech business activities. Nowadays, digital technologies and their widespread usage have created opportunities for radically new business models' development, for getting unique experience in human resources management and for optimizing the internal processes of an international company. Due to the global expansion of Internet, even new and small companies are able to sell their products around the world. More and more companies are growing at a fast pace without making significant investments. Using digital technologies, companies are able to reduce costs and at the same time improve the efficiency and productivity of labor force. Simultaneously with the spread of universalization and unification of processes that are stimulated by digitalization, the asymmetry of economic and social life is enhanced. This is due to the unevenly distributed access to the opportunities provided by the global network. The labor market becomes global, while remaining heterogeneous and controversial.

Analysis of recent research and publications. $N$. Negroponte [1] studied the influence of digital technologies into the transformation of modern society; D. Tapscott [2] analyzed the Internet's impact on the way of doing business; the transformation of labor relations in the global digital economy is covered in the works of U. Huws [3]; the particular aspects of the digital transformation of business are described by N. Fenwick [4]; the peculiarities of digitalization of labor market are studied by the OECD Directorate for Science, Technology and Innovation (STI) [5] and by McKinsey Global Institute [6]; the influence of information and communication technologies on formation of digital economy is analyzed by International Telecommunication Union [7], We Are Social Inc. [8], Gartner, Inc. [9] and Statista [10]. The research of scientists and international consulting agencies referred have not lost scientific value, but global trends of digitalization of global economy and labor market need further examination.

Main purpose of the article is to determine the peculiarities of the transformation of business and the labor market that occurs in the conditions of technologization, informatization and digitalization of the economy and society.

Presentation of the main research results. Influence of the Internet on all aspects of economic life can be considered as a source of the emergence of a new type of economy. Digital economy is characterized by its extremely rapid growth, by creation of new opportunities for production and business activity, and by increase in jobs. Regular economic activity on the Internet using its capabilities has led to the emergence of a new concept - business digitalization.

The usage of the Internet is one of the key factors affecting the digitalization of economy and labor market. Based on the report of International Telecommunication Union "Measuring the Information Society Report 2018", as of the end of 2018, $51,2 \%$ of individuals, or 3,9 billion people, used the Internet [7]. In developed countries, four out of five people have the Internet connection, which mostly corresponds to the saturation level. At the same time, in developing countries, where just $45 \%$ of the population use the Internet, there are still big opportunities for growth. In 47 least-developed countries of the world (LDCs), the rates of the Internet spread are relatively low, namely four out of five people $(80 \%)$ still do not use the Internet.

In 2018 , almost $60 \%$ of households in different countries had access to the Internet at home, however, in 2015 there were less than $20 \%$. In the world less than half of households have a computer at home, by the way significant number of households have the access to the Internet through other means, primarily through mobile devices, often using mobile-broadband subscriptions. In $2017,75 \%$ of the world's population had 
a mobile phone, but in the LDCs, the proportion of such a population was $56 \%$. The majority of new users appeared on the network due to lower prices of smartphones and tariff plans for mobile communications, which became available to the wider population. In 2017, more than 200 million people purchased a mobile device for the first time. In 2018, Northern and Western Europe was one of the regions with the largest spread of the Internet, where $90 \%$ of population were Internet users (fig. 1) [8].

Despite the fact that Middle Africa and Central Asia still have low Internet connection, these regions have the fastest growth rates. The maximum growth rates of Internet connections were observed in African countries, where the number of Internet users increased by more than $20 \%$.

The use of social networks continues to grow rapidly. Nowadays, more than three billion people around the world visit social networks at least once a month, nine out of ten users have the access through mobile devices. The percentage of users of social networks in 2018 was $42 \%$ of the world's population.

Technological changes occurring in digital economy can create new market rules for doing business. In such environment, companies should look for new competitive strategies and increase their effectiveness during competition. Companies have to improve their own competence in the field of digital information technologies to survive and at the same time to develop their business in new conditions.

The digitalization of business should be considered as the source of deep systemic transformations in the economy and involves the usage of digital technologies at the business level to optimize business processes, increase company productivity and improve interaction with customers. In the majority of cases, the goal of digitalization is to meet the needs of consumers, which are changing along with the development of technologies, namely the creation of more comfortable and operational customer interaction with the company. The main tasks of business digitalization are:

- the improvement of product (or service), its quality, attractiveness, usability and delivery;

- the automation of production and other internal business processes;

- the simplification of internal and external communications.

In the era of rapid changes of global economy, a business cannot operate using old models. Digital transformation is a vital necessity for business, so business leaders should be prepared for the digitalization. Otherwise, there is a big risk to stay behind competitors. The main advantages of business digitalization are to strengthen the level of competitiveness; to save the costs (with an effective approach); to simplify the data handling; to create the positive image of company; to increase the loyalty of customer to the brand.

The use of modern digital technologies is necessary for every type of business. The digital minimum for any company is the functioning of website and accounts in social networks. The creation of mobile application for business gives an opportunity to reach a new level of cooperation with customers and suppliers.

The fundamental digital transformation affects not only customer service, but also deep business processes such as production, human resources management and internal communications. Therefore, digitalization is relevant for medium-sized enterprises and large companies.

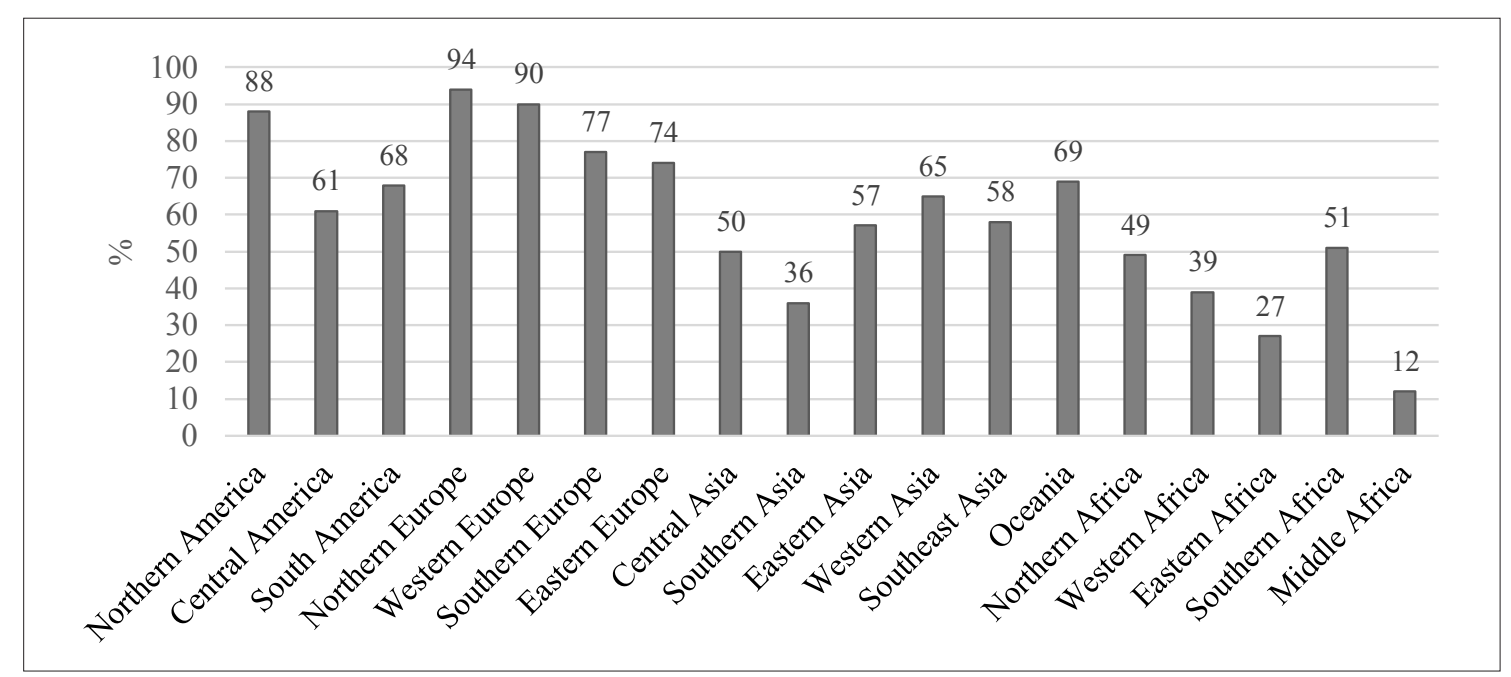

Figure 1. The spread of the Internet connections in different regions, \%, 2018

Source: created by author using [8] 
A small business might be confined to the usage of several digital tools. In many cases, digitalization is important for all sectors, namely business-to-consumer (B2C), business-to-business (B2B) and business-to-government (B2G). Nowadays, IT industry, banking sector and trade are fully involved in the digitalization. In general, the digitalization of business runs in three stages:

1. The analysis of company's activities, goal setting and strategy development. At this stage, it is necessary to analyze all business processes and strategic assets of company, to determine the effectiveness of all its departments, production, internal and external communications, and decide how to improve the activity of company with the help of digital technologies. It is essential to set a clear goal to which the company should come through digitalization and create an approximate strategy to achieve this goal. When drafting a strategy, it is important to remember that new technologies should not completely change the business, their main goal is to simplify business processes.

2. The introduction of digital technology. The next stage can be started only when a clear action plan has been defined, specialists will be found and necessary digital tools will be chosen. The stage of introduction of new technologies includes testing technologies, correcting technical errors, training employees and clients to work with digital services.

3. The analysis of results. After the implementation of each digital solution, top-management should analyze its effectiveness and must be sure that it brings additional income or any other benefit to the company. If this does not happen, then the company should reconsider its approach to the implementation of a specific digital technology.

The term "transformation" in the aspect of business relations is used to describe the process of making changes that business must go through in order to function in the digital economy. Transformation affects all aspects of business from strategic tasks to infrastructure. In modern companies, digitalization is associated more with the transformation of a business operation than with technological modernization [9]. Digital transformation occurs in several areas at the same time.

1. Customer service. The company should use different channels for communication with customers. In the conditions of digitalization, the system should have tools of analytics, scoring, adaptability, forecast and variability. Customer service should be timely, convenient, comfortable and fast. Therefore, the business must use all the tools to adapt to the rapid changes in the culture of consumption and communications.
2. Value-creating system. Due to the rapid change of clients' buying behavior, companies need to create a new value-added services system for their customers. Nowadays, more and more digital firms are providing services or selling products remotely with round-the-clock service support.

3. Data handling. Based on the information collected about the client, the company models its behavior, predicts demand and adapts products and services for them. Data collection, data sorting, analysis and evaluation of information are very time-consuming and important processes for a company, which take a lot of time without automatization of data handling.

4. Innovation introduction. New technologies and modern methods of project management and analytics allow companies to create innovative products and solutions in their innovation centers that regularly search for new directions in business development.

5. Infrastructure development. A business should find non-standard solutions for the development of its product line. To achieve this aim faster it is highly recommended to carry out collaborations and integration with other companies. Digital transformation of partnerships is an important step in scaling a business. Digitalization of infrastructure gives the opportunities to conduct the business without georeferencing to a specific location.

6. Human resources management. For a successful digital business modernization, it is essential to motivate the staff and prepare employees for the introduction of innovations, as doing business methods will be changed dramatically and company will move from an outdated marketing model to a customer-centric system. Both employees and top-management should be ready for continuous development and advanced training [4]. In addition to innovative technologies, digitalization, will introduce into the company new staff units and even divisions.

In the process of economy digitalization, two main directions can be distinguished: the increase in the productivity of business activities and the creation of digital enterprises. Firstly, the digitalization of business operations allows responding quickly and flexibly to changing market conditions and customer needs. Network technologies, production monitoring and innovative concepts enable companies to optimize their production processes. This requires consistent implementation of all stages of digitalization from the formulation of idea to the production of new goods. Secondly, in the global economy it is becoming increasingly difficult to survive if the company is not a digital business. Therefore, these days, 
many companies are turning to cloud services. Digital enterprises are created by cloud technology and consist of remotely working groups. For example, the following companies are actively using digital technologies in their business operations: "Alphabet Inc.", "Amazon.com, Inc.", "Tencent Holdings Limited", "Facebook, Inc.", "Alibaba Group Holding Limited", "Netflix, Inc.", "Priceline.com", "Baidu, Inc.", "Salesforce.com" and "JD.com, Inc." (table 1) [11].

According to the report "Digital Economy Compass 2018" of analytical agency "Statista", the total volume of the e-commerce market in the consumer goods sector grew by $16 \%$ last year. In 2017, annual spending on online shopping reached USD 1,5 trillion [10]. Nowadays, 1,77 billion people buy consumer goods using e-commerce platforms. Approximately $45 \%$ of all Internet users make purchases at e-commerce sites, but the level of penetration of e-commerce differs by country. The highest level of e-commerce penetration is observed in the UK $(78 \%)$, South Korea (74\%), Germany (74\%), Sweden (70\%) and the USA (69\%).

The digitalization of the labor market is a new phenomenon in the global economy, which is characterized by exponential increase in the number of electronic labor exchanges, online labor platforms, freelance service marketplaces that form a single global labor market. Formation of a single digitalized labor market gives any business access to a large number of mobile workers with specific and unique skills to solve actual business issues. In OECD countries, the share of mobile workers who choose a non-standard form of work is $33 \%$ of total employment [5]. Digitalized work involves the execution of various types of work by an employee remotely from an employer's geographical location using digital technologies and mobile applications through electronic labor exchanges and online labor platforms, namely "Fiverr", "Upwork", "Freelancer.com", "Envato Studio", "PeoplePerHour", "Toptal", "Guru.com", "DesignCrowd", "Nexxt", "DesignContest", etc. (table 2) [12].

According to McKinsey Global Institute, by 2025, the electronic labor exchanges and online labor platforms will create 72 million full-time jobs, which will provide world GDP growth of USD 2,7 trillion (or 2\%) [6]. The digitalization of the labor market is characterized by the following features: 1) the increase in the volume of work performed through the usage of digital technologies; 2) the increase in the number of electronic labor exchanges and online labor platforms (intermediaries between employees and employers); 3) the growth of the total number of independent professionals and self-employed freelancers; 4) the distribution of new forms of work based on temporary employment contracts, zero employment contracts and umbrella contracts; 5 ) the spread of crowdsourcing, namely attracting "smart crowd" for the joint search of effective business solutions. Nowadays, multinational corporations are turning to freelance professionals through online platforms for solving internal data processing issues, which simplifies and speeds up the process of searching for the required pool of highly qualified labor force.

Conclusions and prospects for further research in the field. It should be noted that the availability of the Internet for modern society is a necessity,

Top 10 Internet companies by market capitalization in 2018

\begin{tabular}{|c|l|l|c|c|}
\hline Rank & \multicolumn{1}{|c|}{ Company } & \multicolumn{1}{|c|}{ Industry } & Country & $\begin{array}{c}\text { Market } \\
\text { capitalization, } \\
\text { billions USD }\end{array}$ \\
\hline 1 & Alphabet Inc. & $\begin{array}{l}\text { Internet-related services and products and } \\
\text { contextual advertising }\end{array}$ & USA & 763,03 \\
\hline 2 & Amazon.com, Inc. & $\begin{array}{l}\text { Cloud computing, e-commerce, artificial } \\
\text { intelligence and computer hardware }\end{array}$ & USA & 707,75 \\
\hline 3 & $\begin{array}{l}\text { Tencent Holdings } \\
\text { Limited }\end{array}$ & $\begin{array}{l}\text { Internet-related services and products, } \\
\text { entertainment, artificial intelligence and } \\
\text { technology }\end{array}$ & China & 535,00 \\
\hline 4 & Facebook, Inc. & Social networking service & USA & 521,40 \\
\hline 5 & $\begin{array}{l}\text { Alibaba Group } \\
\text { Holding Limited }\end{array}$ & $\begin{array}{l}\text { E-commerce, online auction, hosting, } \\
\text { online money transfer }\end{array}$ & China & 479,43 \\
\hline 6 & Netflix, Inc. & Entertainment and mass media & USA & 121,62 \\
\hline 7 & Priceline.com & Online travel services & USA & 88,68 \\
\hline 8 & Baidu, Inc. & $\begin{array}{l}\text { Internet-related services and products and } \\
\text { artificial intelligence }\end{array}$ & China & 86,25 \\
\hline 9 & Salesforce.com & Cloud computing and software & USA & 81,76 \\
\hline 10 & JD.com, Inc. & E-commerce & China & 66,83 \\
\hline
\end{tabular}

Source: created by author using [11] 
Table 2

Top 10 online labor platforms in 2019 according to the FinancesOnline.com ranking

\begin{tabular}{|c|c|c|c|c|}
\hline Rank & Online platform & Type of platform & Platform's features & Headquarters \\
\hline 1 & Fiverr & $\begin{array}{l}\text { Freelance } \\
\text { marketplace, } \\
\text { online outsourcing }\end{array}$ & $\begin{array}{l}\text { - secure / private communication } \\
\text { channels; } \\
\text { - easiness of services selling; } \\
\text { - secure personal data }\end{array}$ & Israel \\
\hline 2 & Upwork & $\begin{array}{l}\text { Freelance } \\
\text { marketplace }\end{array}$ & $\begin{array}{l}\text { - easy billing; } \\
\text { - in-app communication channels; } \\
\text { - easy and secure payments }\end{array}$ & USA \\
\hline 3 & Freelancer.com & $\begin{array}{l}\text { Freelance } \\
\text { marketplace }\end{array}$ & $\begin{array}{l}\text { - safe and secure payments; } \\
\text { - easy progress monitoring; } \\
\text { - fuss-free job hunting solutions }\end{array}$ & Australia \\
\hline 4 & Envato Studio & Freelancing website & $\begin{array}{l}\text { - easy-to-use solution; } \\
\text { - easiness of job hunting; } \\
\text { - feedback provision in real-time }\end{array}$ & Australia \\
\hline 5 & PeoplePerHour & $\begin{array}{l}\text { Freelance service } \\
\text { marketplace }\end{array}$ & $\begin{array}{l}\text { - financial protection; } \\
\text { - regional recruitment }\end{array}$ & UK \\
\hline 6 & Toptal & $\begin{array}{l}\text { Freelance } \\
\text { marketplace }\end{array}$ & $\begin{array}{l}\text { - easily integrating with work } \\
\text { environments; } \\
\text { - trial period; } \\
\text { - quick recruitment }\end{array}$ & USA \\
\hline 7 & Guru.com & $\begin{array}{l}\text { Freelance } \\
\text { marketplace }\end{array}$ & $\begin{array}{l}\text { - robust dashboard; } \\
\text { - easy and secure payments; } \\
\text { - long-term relationships }\end{array}$ & USA \\
\hline 8 & DesignCrowd & $\begin{array}{l}\text { Online crowdsourcing } \\
\text { platform }\end{array}$ & $\begin{array}{l}\text { - marketing and promotion of } \\
\text { designs; } \\
\text { - easy freelancer payments }\end{array}$ & Australia \\
\hline 9 & Nexxt & $\begin{array}{l}\text { Cloud-based } \\
\text { freelance platform }\end{array}$ & $\begin{array}{l}\text { - easy job search; } \\
\text { - better communication }\end{array}$ & USA \\
\hline 10 & DesignContest & $\begin{array}{l}\text { Professional designer } \\
\text { marketplace }\end{array}$ & $\begin{array}{l}\text { - one platform for designers and } \\
\text { buyers; } \\
\text { - impeccable reputation; } \\
\text { - long-term relationships } \\
\end{array}$ & USA \\
\hline
\end{tabular}

Source: created by author using [12]

because mostly all spheres of modern life are transferred to the digital space. Companies that want to remain leaders should adapt to the digitalization of the economy and labor market. Modern business needs to reorganize key business activities, starting with human resources management and ending with marketing processes. All over the world, there is an increase in the volume of operations that are carried out online (e-commerce, digital marketing, foreign exchange transactions and online recruitment). The online activity changes rapidly: Internet users are becoming more mobile; desktops are systematically replaced with more convenient devices, namely smartphones and tablets. Nowadays, in the digital economy, the number of independent self-employed professionals, who work through online labor platforms, is significantly increasing. However, access to the opportunities offered by the global network is unevenly distributed throughout the world. This indicates that the digital economy and the labor market have not exactly reached the peak of the development. Therefore, this problem will be analyzed in further studies.

\section{References:}

1. Negroponte, N. (1995). Being digital. New York: Alfred A. Knopf, Inc.

2. Tapscott, D. (2014). The Digital Economy Anniversary Edition. New York: McGraw Hill.

3. Huws, U. (2014). Labor in the Global Digital Economy: The Cybertariat Comes of Age. New York: NYU Press.

4. Fenwick, N., Matzke, P., Mulpuru, S., Gill, M., Wang, C., Klehm, R. and Traikovich, K. (2015). The State of Digital Business, 2015 to 2020. By 2020, Execs Expect to See the Majority of Their Revenues Driven by Digital - Are You Ready?. [online] Forrester Research, Inc. Available at: https://www.odgersberndtson.com/media/2545/state-of-digital-business-2015-odgers-berndtson. pdf (Accessed 27 May 2019). 
5. New Forms of Work in the Digital Economy. (2016). OECD Digital Economy Papers, No. 260. [online] Paris: OECD Publishing. Available at: https://www.oecd-ilibrary.org/science-and-technology/newforms-of-work-in-the-digital-economy_5jlwnklt820x-en (Accessed 24 May 2019).

6. Manyika, J., Lund, S., Robinson, K., Valentino, J., and Dobbs, R. (2015). A Labor Market That Works: Connecting Talent with Opportunity in the Digital Age. [online] New York: McKinsey Global Institute. Available at: http://www.mckinsey.com/global-themes/employment-and-growth/connecting-talent-with-opportunity-in-the-digital-age (Accessed 24 May 2019).

7. Measuring the Information Society Report 2018 - Volume 1. (2018). [online] Geneva: International Telecommunication Union. Available at: https://www.itu.int/en/ITU-D/Statistics/Documents/publications/misr2018/MISR-2018-Vol-1-E.pdf (Accessed 24 May 2019).

8. We Are Social. (2018). Digital in 2018: World's Internet Users Pass the 4 Billion Mark. [online] Available at: https://wearesocial.com/us/blog/2018/01/global-digital-report-2018 (Accessed 28 May 2019).

9. Gartner. (2014). Gartner Identifies Six Key Steps to Build a Successful Digital Business. [online] Available at: https://www.gartner.com/en/newsroom/press-releases/2014-05-21-gartner-identifiessix-key-steps-to-build-a-successful-digital-business (Accessed 28 May 2019).

10. Statista. (2018). Digital Economy Compass 2018. [online] Available at: https://www.statista.com/ study/52194/digital-economy-compass/ (Accessed 28 May 2019).

11. Investopedia. (2019). World's Top 10 Internet Companies. [online] Available at: https://www.investopedia.com/articles/personal-finance/030415/worlds-top-10-internet-companies.asp (Accessed 28 May 2019).

12. Financesonline.com. (2019). 20 Best Freelance Websites for Beginners and Professionals in 2019 - Financesonline.com. [online] Available at: https://financesonline.com/top-20-freelance-websites-for-beginners-and-professionals (Accessed 28 May 2019). 